\title{
イラストであらわす手術記録 てんかん外科手術
}

越智さと子，三國 信啓

札幌医科大学医学部脳神経外科

\section{症例；疾患と手術部位}

症例，右側頭葉内側海綿状血管腫（cavernous angioma：CA）による側頭葉てんかんの右利き 8 歳女児.

多発性 CA で, 4 年前右側頭葉脳内出血で発症し血腫 除去術, 2 年後 $\mathrm{CA}$ 摘出後も側頭葉最内側に遺残 $\mathrm{CA}$ を認 めていた。意識減損発作の増悪と発達の遅滞，血管腫の 増大を認め脳幹に接したため（Fig. 1) アプローチを変え て再摘出術を行った。 Zygomatic arch を外し右前頭側頭 開頭と側頭下アプローチで側頭葉内側底部を直視下にお き脳幹周囲を確認した。切除前に右側頭葉皮質上で electrocorticogram（ECoG）を測定し（Fig. 2C, D), sub temporal に側頭葉内側に至った。癒着を剝離し ambient cisternを開放, 動眼神経, 内頝動脈 (internal carotid artery： ICA), 後交通動脈 (posterior communicating artery： PcomA）を確認した。側頭葉底内側と（Fig. 2B）, 脳幹 表面にへモジデリン沈着による変色, 血管腫への小血管 を認めた。血腫内減圧し CA を全摘した。側頭葉底や外 側皮質の皮質脳波を再確認し, 棘波を認める 2 電極分 (赤 線）の皮質切除を加えた（Fig. 2D）。吸収プレートを用 い閉頭した ${ }^{3)}$.

\section{手術イラストレーション＼cjkstart描き方, こだわり}

(1)輪郭 ; 外表面の輪郭や，頭蓋骨の解剖学的描画を 作っておき，体位や皮切部位，開頭部位を記載する。

(2)術中イラスト; 術野で最も確認するべき解剖学的構 造物を中心に，位置関係を考え，鉛筆で大まかなドラフ 卜を描く. 静止画で見直しつつ表面側から梁部へ(皮弁, 骨縁，硬膜，主静脈，動静脈，脳槽の脳神経，テント， falx など)，構造物を描きこむ。 Labbe v., sylvian v., bridging v. の走行や分岐をメルクマールとし 3 dimension CT angiography（3DCTA）を参考に，中心溝，弁蓋部，角 回，上中下側頭溝などを同定する，硬膜下電極の位置， 方向，深部電極抻入部などを術中メモも参考に確認し， 追記する。

(3)彩色; 表面を淡く, 深部を濃く描くと遠近感が出る. 近隣構造物は，補色や色調で区別，脳溝や太い血管は影 をつける。

(4)先人に倣い ${ }^{1)}$ ，バイポーラー，吸引管，脳ベラなど を描き加えると, 注目すべき部位が強調され臨場感が出 る. 術野の邪魔にならない部位に強く明確に描き入れ，影 線は深部で細く密に, 表面では間隔をあけて描く. 全体図 の方向 (anterior, posterior, midline, lateral, ventral, caudal, right, left など) や, 解剖学的名を略語も使って記入する.

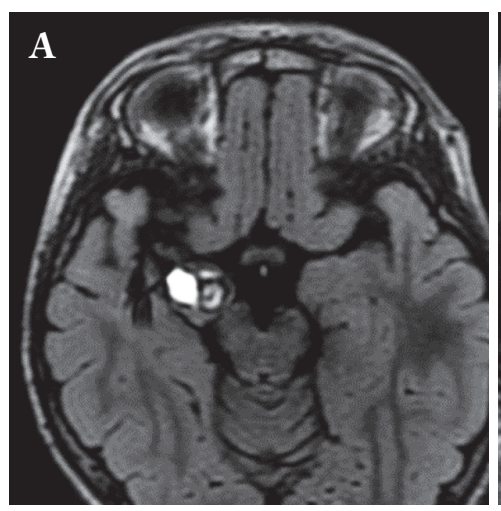

A : MRI T1WI Axial.

B : Coronal.

C : FDG-PET Axial view.
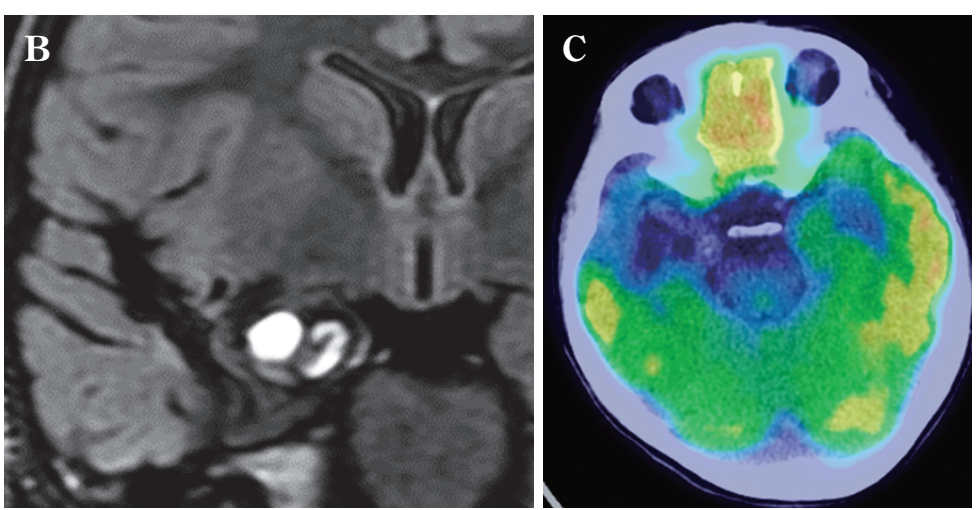

Fig. 1 提示症例 


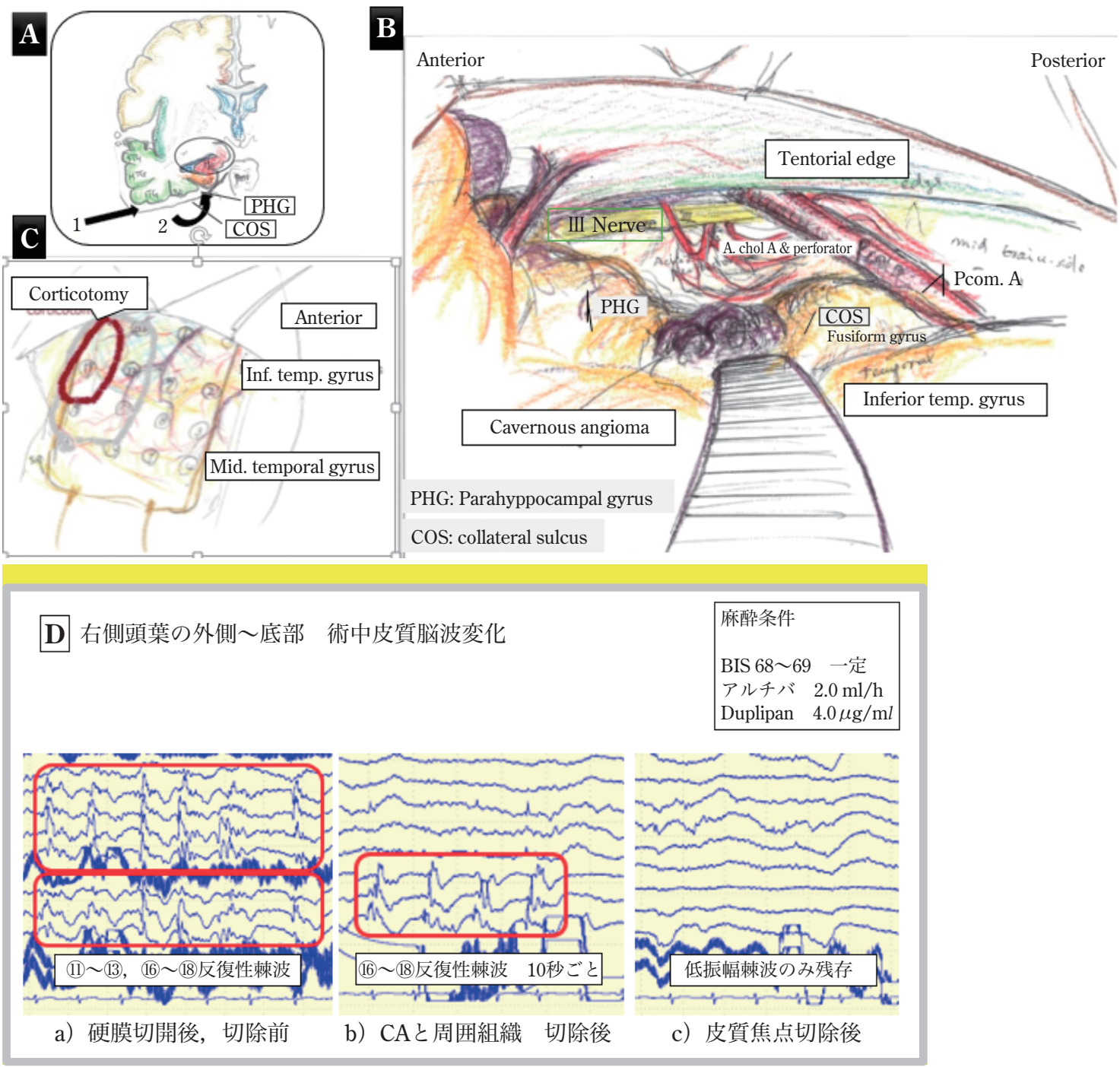

A : Rt. subtemporal approach.

Fig. 2 提示症例の手術イラスト

B : Rt. subtemporal hipoccampal CA resection.

$\mathrm{C}$ ：側頭葉外側皮質 $\mathrm{ECoG}$ と棘波，焦点皮質切除範囲。

$\mathrm{D}$ : 術中 $\mathrm{ECoG}$ 変化 (a: 切除前 $\mathrm{b}$ : CA 切除後 $\mathrm{c}$ : 皮質焦点切除後).

\section{こだわり}

彩色は 12 色の色鉛筆を用い，同じ赤でも明るさ色調 を変える、今回は，ヴァン・ゴッホ色鉛筆（ターレンス 社輸入品）を用いた。作画は，脳表（orange+ perm yellow), 白質 (perm yellow light + deep), 動静脈 (scarlet と輪郭黒, 静脈は perm blue violet + ultramarine), 硬膜 系は深部ほど暗い色調を意識した（burnt sienna+turquoise blue + perm green deep など). 神経 (yellow light + deep), くも膜（turquoise blue + ultramarine）などを用い た (Fig. 3, 4).

\section{指導法}

術前カンファレンスでは, 研修医が体位・皮切, 開頭 野，術野を想定したスケッチを提示し，開頭部位は頭蓋 骨イラストに想定骨孔位置や craniotomy 範囲, 静動脈の 走行などを描く，正確を期すよう指導が入り，上手な術 野表現のポイントを考えるようにすると，回を追うごと に上達する。若手の先生方は PC 描画ソフトや画像貼り 付けを使うことが多く，実際に手描きイラストの指導を する機会は残念ながら少ない.イラスト像は必ずしも見 たままの, ビデオや静止画どおりではなく, 手術に関連 する重要構造物を俯瞰的に捉え得る点に意味がある。繰 


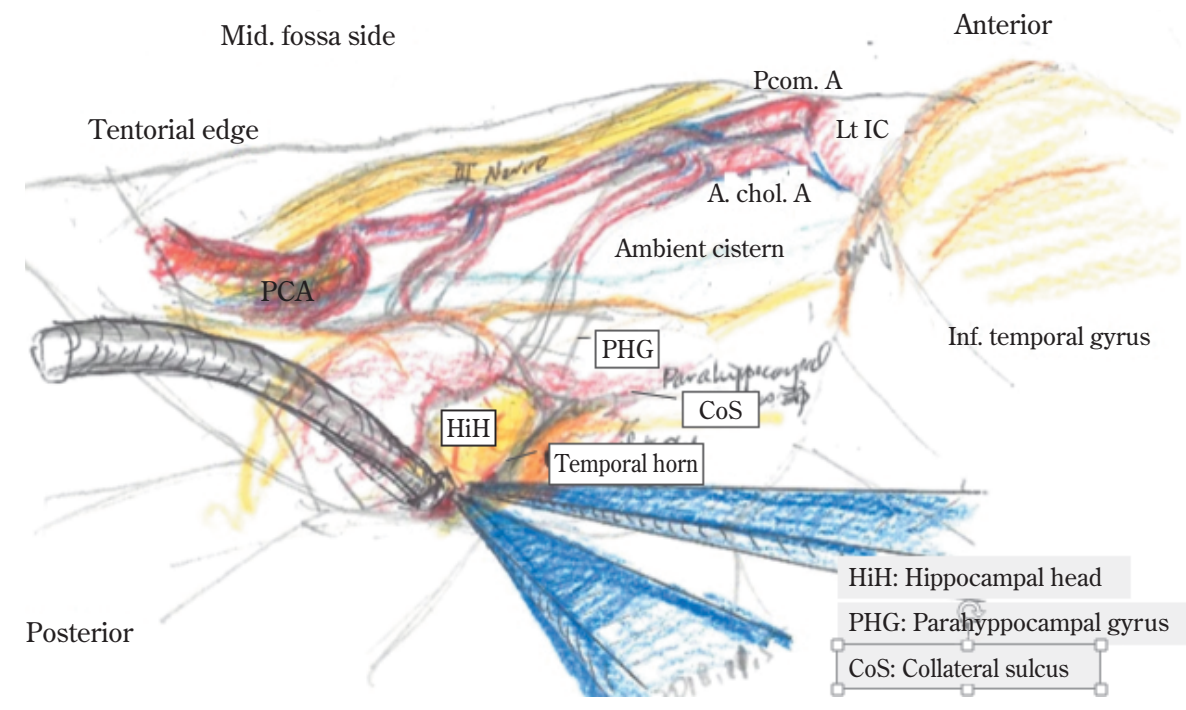

Fig. 3 類似症例 ; 左側頭葉てんかんの手術イラスト

Lt. subtemporal hippoccampal resection

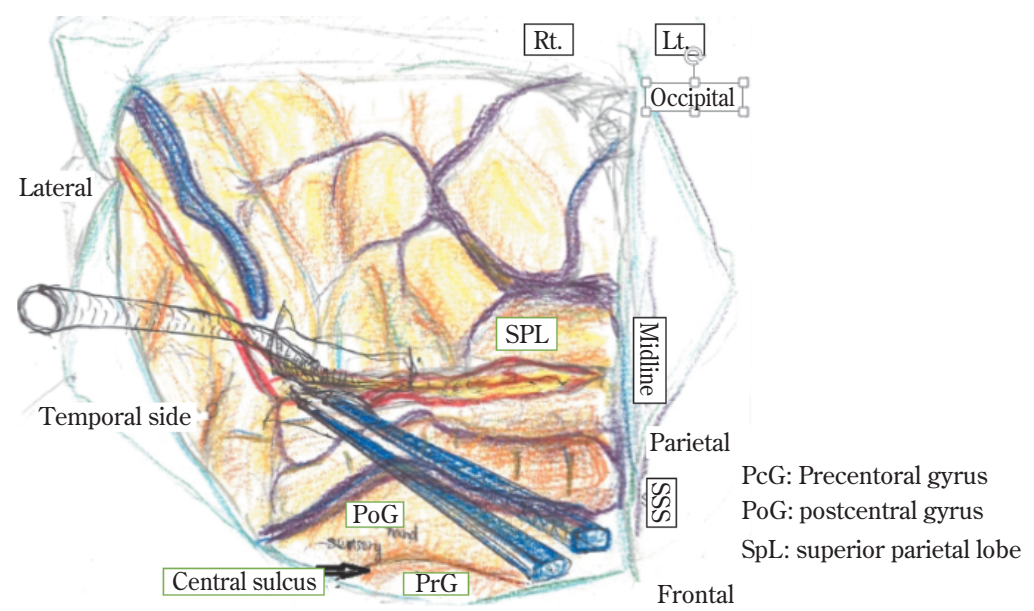

Fig. 4 脳葉離断術の手術イラスト

Rt. posterior quadrant disconnection.

り返し見直す経過で，病態や術者の意図，留意点などが みえてくるので, 教育的意義を強調したい.

\section{実際の手術イラスト}

提示症例の切除部進入方向と術中 $\mathrm{ECoG}$ 変化を示した (Fig. 2). 左海馬硬化症を伴う左側頭葉てんかん症例に 対する subtemporal approach での海馬扁桃体切除術 (Fig. 3）と両側後頭葉大脳形成不全を伴う小览症例に対する 右後頭葉離断術 ${ }^{2}$ での脳溝や静脈走行を示す（Fig. 4).

\section{考 察}

マイクロ手術 stand up surgery の導入で，モニタリン グ側も術者の手を止めずに電極位置情報を共有できるよ うになった。このような時代，手描きイラストはいよい よ不要かもしれないが，視覚認知は気になるところ以外 を無視してしまう。動静脈の走行, 脳溝の解剖学的位置 関係同定は，焦点や機能部位確認にとりきわめて重要 で, 術前検査や，術中モニター所見，術後結果を再確認 するうえで，手描きのイラストには意義があると考え る。症例ごとに，特異な点の情報を共有，再確認し，機 能外科治療成績向上や, 将来につなげていきたいと思う. 
COI 開示

著者は日本脳神経外科学会へのCOI自己申告の登録を完了

しています。

本論文に関して開示すべきCOI はありません。

\section{文 献}

1）馬場元毅：Dr. Baba のメディカルイラストレーション講 座。東京，三輪書店，2017。
2) Daniel RT, Babu KS, Jacob R, Villemure J : Posterior Quandrantic Resection and Disconnection. in Çataltepe O, Jallo GI (eds) : Pediatric Epilepsy Surgery. Stuttgart, Thieme, 2010, pp.196-204.

3）三國信啓：側頭葉腫瘍性病変によるてんかんの治療方 針。脳外誌 24 Supple 2：58-63，2015.

4) Yasargil MG: Limbic and Paralimbic tumors. in Micro neurosurgery IVB Micronueurosurgery of CNS Tumors. Stuttgart, Thieme, 1995, pp.252-290.

\section{要旨}

\section{イラストであらわす手術記録 てんかん手術}

\section{越智さと子 三國 信啓}

てんかん外科治療はチーム医療で諸検査を基に評価，適応検討し，術中モニタリングに関わる医師 も情報を共有する．術記録には簡単な経過と治療目的を記載する．体位，開頭野を記載後，脳溝や機 能野などを解剖学的に同定し, 皮質脳波（electrocorticogram：ECoG）の電極位置などをモニタリン グ結果とともに記載するとよい. メルクマールの構造物として, 脳神経や主要血管と分枝など, さら に脳表の所見（腫大, 変色, 血管変化など）も記載する. 当院では,てんかん緩和外科治療を選んだ 場合, 原則迷走神経刺激療法（vagus nerve stimulation：VNS）を先行し，2 年経過後も改善が不十分 な場合に脳梁離断術（corpus callosotomy：CC) や脳葉離断術を追加する方針としている. したがっ て, CC 症例は VNS 留置例が多く, 術中 ECoG で離断効果や脳波変化を確認しており,これらも記載 する. VNS 留置術は定型的ながら，体位や皮切位置，迷走神経モニタリング結果を付記するととも に，機器システム（ロットとシリアル番号）を記載することが重要である. 


\section{Editorial Comment}

\section{手術イラストを描いてキーとなる術野を目に燒きつけよう}

著者らは, 右側頭葉内側海綿状血管腫による側頭 葉てんかんの症例に施行したてんかん手術の記録を 提示している. Subtemporal approach で側頭葉内側 に到達して血管腫を摘出, さらに術中皮質脳波に基 づいて追加皮質切除を行った手術の過程を，概念図 や実体イラストを駆使して表現し,てんかん外科手 術における手術記録記載の要点を示した。

てんかん外科では, 標準的側頭葉切除術, 選択的 海馬扁桃体切除術, 脳梁離断術, 大脳半球離断術, 迷走神経刺激装置植込術など, 定型的な手術が行わ れることが多い。これらの手術では脳腫瘍や脳血管 障害の手術に比べると症例ごとの解剖学的バリエー ションは比較的小さい. 動脈溜や聴神経腫瘍などで は，血管や神経が術中にどのように見え，それに対 してどのように対処したかをわかりやすく示すとこ ろに手術イラストの意義があるが，てんかん外科の 定型的手術では，1枚のイラストでは表現困難な側
自治医科大学脳神経外科 川合謙介

頭葉内側切除術や大脳半球離断術の複雑な過程を各 段階のキーとなる複数のイラストや概念図を用い て，わかりやすく記録することが求められる。

側頭葉内側切除術や全脳梁離断術, 大脳半球離断 術などを確実に遂行するためのポイントは, 各段階 の術野をしつかりと展開することにあると私は考え ている。そのためには, 各ステップでキーとなる術 野を眼に焼きつけておくことが要求され, 若手脳神 経外科医にとつて手術書と手術ビデオを見比べなが ら重要なステップのイラストを描くという作業は, 手術の習得にとつてきわめて有用な訓練になるもの と信じている. 働き方改革の名の下に労務時間と自 己研鑚時間の区別が云々される時代となったが，こ のような訓練は無償の自己研鑽以外の何物でもな い.しかし，このような研鑽の積み重ねこそ数年後 に大きな差を産むのである。 